\title{
Bioconversion of Baltic Seaweeds into Organic Compost
}

\author{
Izabela Michalak $^{1} \cdot$ Radosław Wilk $^{1} \cdot$ Katarzyna Chojnacka $^{1}$
}

Received: 6 May 2016/Accepted: 11 October 2016/Published online: 17 October 2016

(c) The Author(s) 2016. This article is published with open access at Springerlink.com

\begin{abstract}
Purpose Large quantities of green seaweeds, resulting from the eutrophication, are cast ashore on the beaches of Baltic Sea (Poland). There is a necessity to collect this biomass and dispose in a cost-effective and environmentalfriendly method. In the present paper, preliminary study on the possibility of composting of Baltic algae is described. After 8 weeks, algal compost and compost extract were produced. The obtained bio-products are expected to enhance plant growth and crop yield since seaweeds are known to be rich in macro- and microelement nutrients, amino acids, vitamins and plant growth promoting substances.

Methods The obtained compost and compost extract were characterized in terms of the content of micro- and macroelements and toxic metals. The phytotoxicity of products were then biologically evaluated in germination tests on garden cress (Lepidium sativum) and radish (Raphanus sativus). In the control group, both plant species were watered with distilled water. After the experiment, dry weight of the cultivated plants was measured. Moreover, yield and the content of and micro- and macronutrients in plants was determined.

Results Results showed that there were no phytotoxic effects in both cases and the addition of compost and extract increased the plant growth. The difference in weight for both plants between the examined groups was insignificant. The biomass of plants fertilized with the algal
\end{abstract}

Izabela Michalak

izabela.michalak@pwr.edu.pl

1 Department of Advanced Material Technologies, Faculty of Chemistry, Wrocław University of Science and Technology, Wrocław, Poland compost and extract was biofortified in micro- and macroelements (in particular $\mathrm{B}, \mathrm{Fe}, \mathrm{Cu}, \mathrm{Zn}, \mathrm{Ca}, \mathrm{K}, \mathrm{S}$ ). Conclusions According to these results, composting is a useful technology both to solve waste disposal problems and to produce a valuable organic fertilizer. This could help to reduce the use of chemical fertilizers and improve physicochemical properties of the soil and to increase the plant growth.

Keywords Macroalgae $\cdot$ Baltic Sea $\cdot$ Compost $\cdot$ Compost extract $\cdot$ Natural fertilizer $\cdot$ Plant growth biostimulant

\section{Introduction}

Intense growth of seaweeds and their drifts, being a result of eutrophication in coastal ecosystems is observed [1-4]. In some countries, algal biomass is collected in order to remove nutrients and organic matter from the coastal waters $[1,5]$. Part of this biomass is used as a fertilizer in the nearby land [6], part is designated for the landfill disposal (many disadvantages, e.g., high costs, lack of the area suitable for waste settlement, leachate and biogas production during decomposition of algae) [7], part is allocated for the composting purposes $[1,2,8,9]$. The last option opens interesting prospects for the treatment of seaweeds with the possibility of the recovery of fertilizing value of algal biomass [7]. Recycling of nutrients that minimizes their quantity imported to the farm (especially through the fertilizers) is promoted by the organic agriculture, which seeks for high quality food while respecting the environment and maintaining soil fertility by the optimal use of resources [10]. Seaweeds (fresh and dry) or its products (extracts, composts, soil conditioners) have been used in agriculture for a long time to enhance plant growth and 
productivity [11]. One of the main benefits of organic fertilizers is the release of available nutrients into soil, which may last for several years [12].

Different composting technologies are applied for algal biomass stabilisation. Generally they are divided into three groups: (1) passive piles or windrows-material is left undisturbed and relies on natural convective air flows for aeration; (2) turned or aerated piles or windrows-air is incorporated when the material is mechanically turned and mixed and (3) in-vessel systems-optimum environmental conditions (aeration, moisture, temperature) for the quick decomposition of algal biomass [2, 9]. The obtained compost quality varies with the feedstocks that were used to produce it, the applied methods of pre-treatment of materials before composting, the composting time, the method in which the product is processed after composting etc. [13].

Co-composting of drifting and beach-cast seaweeds is a useful method of utilization of the waste biomass. Marine algae, as a component of the composting mixture, have been tested for the use as a source of elements (micro- and macroelements) and chemical substances (e.g., amino acids, vitamins, plant growth hormones, polysaccharides), which are known to have fertilizer or protective role [14]. There are four main pathways in which macroalgae can contribute to the plant health: (1) nutritional benefits (nitrogen, phosphorous, potassium, trace elements), (2) disease resistance (sulphated polysaccharides), (3) endocrine effects (cytokinins, auxins, gibberellins) and (4) soil conditioning (water holding capacity, beneficial soil biotia) [15].

The obtained algal product in the composting process can be suitable for the agricultural use as a fertilizer, soil amendment or plant growth substrate [1, 16]. By avoiding the use of a treated straw or urban and industrial sludge in the compost as co-composting materials, the produced seaweed compost shows very low content of pesticides, such as organochlorine compounds and cereal growth regulators [5]. Seaweed compost treated as organic fertilizer has several advantages over regular plant compost, especially in the case of the content of micro- (Mn, Zn, I) and macroelements ( $\mathrm{P}, \mathrm{K}, \mathrm{Ca}, \mathrm{Mg}$ ), as well as the content of plant hormones such as total auxins and cytokinins (adenine) ( $\sim 5$ times more) and total amino acids $(\sim 7$ times more) [17].

The second interesting group of algal products are extracts. They are considered as a new generation of products for sustainable agriculture-plant growth biostimulants [18-20]. These liquid products contain highly effective compounds that promote faster germination of seeds, increase the yield and the resistance to the biotic and abiotic stress. Their application may avoid excessive fertilization since they can improve mineral absorption by plants. Unlike, chemical fertilizers, extracts derived from seaweeds are biodegradable, nontoxic, non-polluting and non-hazardous to plants [18]. Seaweed extracts are known to contain nutrients that are essential for plant growth $[18,20]$.

The aim of the present study was to develop a simple method for the conversion of seaweed biomass into natural compost and extract. The obtained products were examined in terms of their phycotoxicity [germination tests on garden cress (Lepidium sativum) and radish (Raphanus sativus)] and multielemental composition using ICP-OES method. Additionally, the effect of algal compost as a natural organic fertilizer and compost extracts as biostimulant on the plant growth was evaluated. The yield and the mineral composition of the cultivated plants were determined.

\section{Materials and Methods}

\section{Raw Material for Composting}

Drifting marine macroalgae were collected from the Baltic Sea near Sopot beach (Poland) in August 2013 when algal biomass was at its annual maximum. Multi-species seaweed biomass consisted of the green algae Cladophora glomerata, Ulva flexuosa, Ulva clathrata and the red alga Polysiphonia fucoides. Then the biomass has been subjected to the following processes: (1) rinsing with tap water immediately after collection to remove salt and sand, (2) removal of bigger impurities such as stones, shells and pieces of wood in a perforated rotary drum, (3) dewatering using hydraulic press (AWELD, Czech Republic), (4) drying in the rotary drum at $<55^{\circ} \mathrm{C}$ (Tessa, Poland) to reduce water content in algae below $15 \%$ [20]. Afterwards, algal biomass was pelleted using a Granulator TL 700 (Gama Pardubice, Czech Republic).

\section{Composting of Algae}

About 1 ton of dry, pelleted Baltic algae underwent composting process. The process was conducted in the open air in a pile with dimensions of approximately $1.5 \mathrm{~m} \times 1 \mathrm{~m} \times 1.2 \mathrm{~m}$, which allowed for the effect of so called "chimney aeration". Moisture was maintained at the level $60-65 \%$ for 6 weeks. The mixture was overturned once a week. The maximum temperature achieved was $38{ }^{\circ} \mathrm{C}$. The temperature was measured (in triplicate) during the process, at various points around the piles, at a depth of $60 \mathrm{~cm}$. The maturity of the compost was evaluated by measuring the parameters such as change of the odour, colour and the structure of compost and performing the phytotoxicity test. The resulting compost was also characterized with respect to chemical composition. 


\section{Extract from the Compost}

From the obtained compost, extract was produced according to the procedure described by Alvarado et al. [21]. Subsequently, $130 \mathrm{~g}$ of the compost was filtered using a funnel with filter paper (Whatman Filter Paper No. 2; GE Healthcare Life Sciences, Little Chalfont, England) and $300 \mathrm{~mL}$ of distilled water. The process was repeated 5 times. An intense brown colour liquid was obtained. The filtrate was considered as $100 \%$ [21]. The obtained extract from the compost was characterized in terms of chemical composition and phytotoxicity.

\section{The Phytotoxicity of Compost-Germination Tests}

The phytotoxicity of compost and compost extract was evaluated in seed germination of cress (Lepidium sativum) and radish (Raphanus sativus). These two plants were chosen because they can reach maturity in short time period (to 2 weeks). Tests were carried out on plates ( $90 \mathrm{~mm}$ diameter) with wool in a germinator-type Jacobsen (Laborset, Lodz, Poland) in the room temperature, according to the international norm (International Rules for Seed Testing, 2011International Seed Testing Association).

Seeds of each plant (50) were placed on a plate $(\mathrm{N}=4$, four replications for each tested group). Then, prepared plates were put for three days into a fridge (stratification process). Tests were performed in three variants: (1) a control group - the growth of plants watered with water $(2 \mathrm{~mL})$; (2) compost - the growth of plants with the addition of compost $(1.0 \mathrm{~g})$ (3) extract obtained from the compost $(100 \%)$ - the growth of the plants watered with extract (2 mL) [22]. All the plates were watered with $2 \mathrm{~mL}$ of water every two days. Germination tests lasted for 9 days. At the end of the experiment, the plants were collected from each plate, dried and the dry mass was weighed. Additionally, the effect of the tested algal product (compost or extract) on the multielemental composition of cultivated plants was evaluated using ICP-OES technique (Inductively Coupled Plasma-Optical Emission Spectrometry).

\section{Analytical Methods}

The analysis of the content of $\mathrm{C}$ and $\mathrm{N}$ in algae and in the compost was made with the Vario MACRO Cube CN analyzer (Elementar Analysensysteme $\mathrm{GmbH}$, Germany). The analysis of the elemental composition of algae, compost, extract from the compost as well as the cultivated plants was performed using ICP-OES iCAP 6500 Axial and Radial Vista (Thermo Scientific, Waltham, Massachusetts, USA) in accordance with PN-EN ISO/IEC 17025:2005. Before multielemental analysis, the samples [about $0.5 \mathrm{~g}$ of dry mass (d. m.)] underwent the mineralization (with $5.0 \mathrm{~mL}$ of $69 \% \mathrm{HNO}_{3}$ ) in Teflon bombs using the microwave oven-Milestone Start D (Milestone S.r.l., Sorisole, Italy).

\section{Statistical Analysis}

The results were analysed with the use of Statistica ver. 12, where statistical significance was established for $p$ values $<0.05$.

\section{Results and Discussion}

The maturity of the obtained algal compost was evaluated by the observation of the following properties: (1) the odour of the compost - change from the intense odour of marine algae into the earthy/humus odour (the change was observed after 5 weeks of the process), (2) the colour of the compost-from dark green to dark brown (after 5 weeks), (3) loosening of the structure of the pellets to the form of loose soil (after 5 weeks), (4) no forms of fibrous material (after 4 weeks).

\section{Elemental Composition of Algal Biomass, Algal Compost and Extract from the Compost}

Scientists working on co-composting of algal biomass suggest that the obtained products could be used as a fertilizer and soil conditioner in agriculture, as they are of a natural origin $[10,23]$ and constitute a rich source of micro- and macronutrients, amino acids, vitamins, plant growth hormones (auxins, cytokines) and polysaccharides such as alginates, ulvans etc. [19]. The quality of the obtained product in terms of the degree of stabilization and the final available nutrients depends mainly on the carbon to nitrogen ratio ( $\mathrm{C}: \mathrm{N}$ ratio) of the organic material being composted. It is an important factor, since affects the microbial compost communities [2]. An initial $\mathrm{C}: \mathrm{N}$ ratio of 20:1-40:1 is recommended for rapid composting. However, C:N ratios as low as 14:1 also compost well and are practical for composting animal mortalities [24].

The content of $\mathrm{C}$ and $\mathrm{N}$ in the raw biomass of algae used in the present study, before composting process, was $20.2 \pm 0.2 \%$ d. m. and N $1.86 \pm 0.02 \%$ d. m (C:N ratio 10.8). Algae are characterised by a relatively low carbon to nitrogen ratio [2], for example $\mathrm{C}: \mathrm{N}$ ratio in green macroalga Ulva sp. was 8.5 [1], 8.8 [25]. The C:N ratio in the obtained algal compost was equal 10.8 (the content of $\mathrm{C}$ was $14.3 \pm 0.2 \%$ d. $\mathrm{m}$. and $\mathrm{N} 1.31 \pm 0.01 \%$ d. m.). The content of $\mathrm{C}$ and $\mathrm{N}$ decreased by 29 and $30 \%$, respectively in the compost when compared with the natural biomass of 


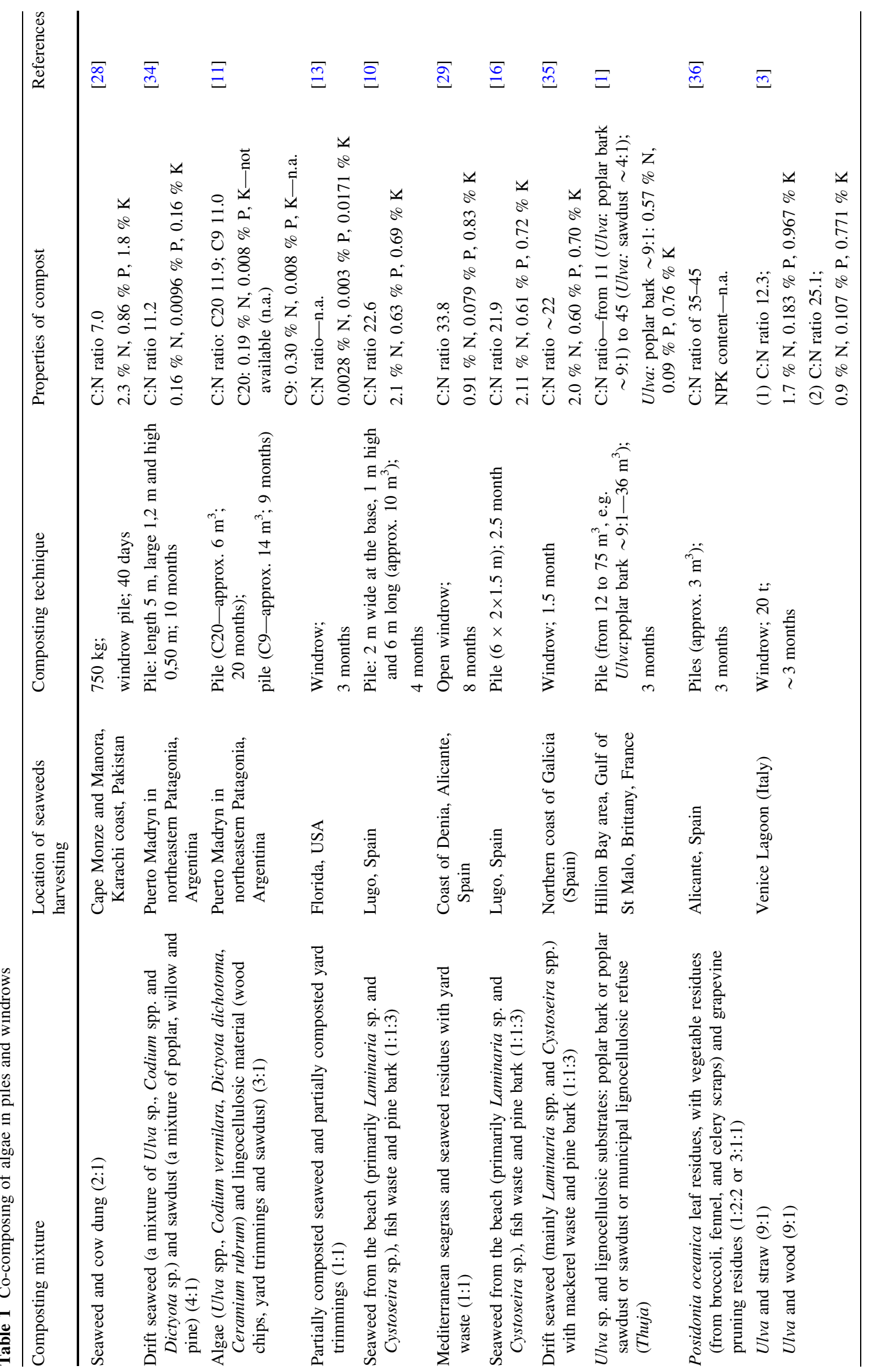


algae. During the composting process, carbon and nitrogen are mineralized and lost in gaseous forms mainly as $\mathrm{CO}_{2}$, $\mathrm{NH}_{3}, \mathrm{~N}_{2} \mathrm{O}$ and $\mathrm{N}_{2}$ [26]. In Table 1, several examples of the composting of algae in piles and windrows are presented. As can be seen, $\mathrm{C}: \mathrm{N}$ ratio in the final compost varies from 7 to 45 .

In Table 2, the multielemental composition of algal biomass, compost and extract from the compost is shown.

Algae are known to have a suitable content of nitrogen and potassium, but are much lower in phosphorus than traditional animal manures and the typical $\mathrm{N}: \mathrm{P}: \mathrm{K}$ ratios in chemical fertilizers [6]. In the present study, the content of $\mathrm{N}, \mathrm{P}$ and $\mathrm{K}$ in the raw biomass of algae was as follows: $\mathrm{N}$ : $1.86 \%$ d. m., P: $0.145 \%\left(0.332 \%\right.$ as $\left.\mathrm{P}_{2} \mathrm{O}_{5}\right)$ and $\mathrm{K}$ : $0.544 \%\left(0.656 \%\right.$ as $\left.\mathrm{K}_{2} \mathrm{O}\right)$. By comparing the macroelemental composition of algal biomass with other natural manures, such as farmyard manure $\left(\mathrm{N}: 0.57 \%, \mathrm{P}\right.$ as $\mathrm{P}_{2} \mathrm{O}_{5}$ : $0.45 \%, \mathrm{~K}$ as $\mathrm{K}_{2} \mathrm{O}: 0.52 \%$ ) and liquid manure (N: $0.42 \%$, $\mathrm{P}$ as $\mathrm{P}_{2} \mathrm{O}_{5}: 0.23 \%, \mathrm{~K}$ as $\mathrm{K}_{2} \mathrm{O}: 0.37 \%$ ) [27], it was found that algae were a richer source of nitrogen and potassium than the compared manures. Additionally, algae contained more phosphorus than liquid manure but less than farmyard manure. The same tendency was observed in the case of the obtained algal compost that contained: N $1.31 \%$ d.m., P: $0.159 \%\left(0.364 \%\right.$ as $\left.\mathrm{P}_{2} \mathrm{O}_{5}\right)$ and $\mathrm{K}: 0.492 \%(0.592 \%$ as $\mathrm{K}_{2} \mathrm{O}$ ). These results are in agreement with the data presented by McHugh et al. [6]. Morand et al. [5] showed that the compost made from green and brown seaweeds, poplar ground bark and laying-hen droppings had higher content of $\mathrm{N}, \mathrm{P}$ and $\mathrm{K}$ when compared to manure of cattle and horses ( $\mathrm{P}$ as $\mathrm{P}_{2} \mathrm{O}_{5}: 1.05 \%$ w. m. (wet mass) and 0.1-0.5\% w. m. respectively, $\mathrm{K}$ as $\mathrm{K}_{2} \mathrm{O}: 1.0$ and $0.1-0.7 \%$ w. m., total $\mathrm{N}$ : 0.85 and $0.3-0.7 \%$ w. m.). The content of $\mathrm{N}, \mathrm{P}, \mathrm{K}$ in compost produced from algae ranges from $0.0028 \%$ [13] to $2.3 \%$ [28] for N; from $0.003 \%$ [13] to $0.183 \%$ [3] for P; from $0.0171 \%$ [13] to $1.8 \%$ [28] for $\mathrm{K}$ (Table 1).

The results obtained in the present study show the increase of micro- and macronutrients in the produced algal compost when compared with the raw biomass ( $\mathrm{Ca}$ by $27 \%, \mathrm{Cu}$ by $11 \%, \mathrm{Fe}$ and $\mathrm{P}$ by $9.0 \%$ ). These findings are in agreement with the results presented by other authors, for example Orquin et al. [29] noted the increase of P, K, $\mathrm{Ca}$ and $\mathrm{Mg}$ in the compost produced from seagrass and seaweed mixed with municipal yard and landscape green waste, Michalak et al. [30] observed the increase of $\mathrm{Ca}, \mathrm{Fe}$, $\mathrm{Zn}, \mathrm{P}, \mathrm{Mg}$ in the compost produced from seaweed Fucus sp., ecological hay, grass, sawdust and spent mushroom substrate, Cole et al. [8] noticed the increase of $\mathrm{S}, \mathrm{Ca}, \mathrm{Fe}$, $\mathrm{Mn}, \mathrm{Zn}$ in the compost made from green seaweed-Ulva ohnoi and sugarcane bagasse biomass. Calcium and iron were the dominant elements.

One of the main disadvantage of the compost produced from seaweed might be the content of toxic metals. Macroalgae are known to accumulate toxic metals [23]. In the present work it was found that the content of toxic elements in the obtained compost was below the maximum acceptable levels: $\mathrm{Cr}(26.02 \pm 3.90<100 \mathrm{mg} / \mathrm{kg} \mathrm{d} . \mathrm{m}$. limits in the obligatory law $), \mathrm{Cd}(0.88 \pm 0.11<5 \mathrm{mg} / \mathrm{kg}$ d. m.), $\mathrm{Pb}(12.54 \pm 1.63<140 \mathrm{mg} / \mathrm{kg} \mathrm{d}$. m.) taking into account Polish regulations [31].

Table 2 Multielemental composition of algal biomass, algal compost and compost extract

\begin{tabular}{llccc}
\hline Element & $\begin{array}{l}\text { Wavelength } \\
(\mathrm{nm})\end{array}$ & $\begin{array}{l}\text { Algal biomass }[\mathrm{mg} / \mathrm{kg} \mathrm{d} . \mathrm{m} ., \\
(\mathrm{mean} \pm \mathrm{SD} ; \mathrm{N}=3)]\end{array}$ & $\begin{array}{l}\text { Algal compost }[\mathrm{mg} / \mathrm{kg} \mathrm{d} . \mathrm{m} ., \\
(\text { mean } \pm \mathrm{SD} ; \mathrm{N}=3)]\end{array}$ & $\begin{array}{l}\text { Compost extract }[\mathrm{mg} / \mathrm{L}, \\
(\mathrm{mean} \pm \mathrm{SD} ; \mathrm{N}=3)]\end{array}$ \\
\hline $\mathrm{Al}$ & 308.215 & $3324 \pm 665$ & $3846 \pm 769$ & $0.55 \pm 0.08$ \\
$\mathrm{~B}$ & 249.773 & $175 \pm 26$ & $146 \pm 22$ & $5.16 \pm 0.77$ \\
$\mathrm{Ca}$ & 315.887 & $13,289 \pm 2658$ & $18,097 \pm 3619$ & $375 \pm 56$ \\
$\mathrm{Cd}$ & 228.802 & $0.93 \pm 0.12$ & $0.88 \pm 0.11$ & $0.01 \pm 0.00$ \\
$\mathrm{Cr}$ & 267.716 & $10.30 \pm 1.54$ & $26.02 \pm 3.90$ & $0.02 \pm 0.00$ \\
$\mathrm{Cu}$ & 324.754 & $23.85 \pm 3.58$ & $26.58 \pm 3.99$ & $0.21 \pm 0.03$ \\
$\mathrm{Fe}$ & 259.940 & $7727 \pm 1545$ & $8460 \pm 1692$ & $3.01 \pm 0.45$ \\
$\mathrm{~K}$ & 766.491 & $5443 \pm 1089$ & $4917 \pm 983$ & $149 \pm 22$ \\
$\mathrm{Mg}$ & 285.213 & $3822 \pm 764$ & $3949 \pm 790$ & $487 \pm 73$ \\
$\mathrm{Mn}$ & 257.610 & $223 \pm 33$ & $189 \pm 28$ & $6.52 \pm 0.98$ \\
$\mathrm{Mo}$ & 202.030 & $0.67 \pm 0.10$ & $0.66 \pm 0.10$ & $0.04 \pm 0.01$ \\
$\mathrm{Na}$ & 588.995 & $5209 \pm 1042$ & $4451 \pm 890$ & $981 \pm 147$ \\
$\mathrm{P}$ & 213.618 & $1449 \pm 290$ & $1587 \pm 317$ & $499 \pm 75$ \\
$\mathrm{~Pb}$ & 220.353 & $10.59 \pm 1.38$ & $12.54 \pm 1.63$ & $0.02 \pm 0.00$ \\
$\mathrm{~S}$ & 181.972 & $8963 \pm 1793$ & $7665 \pm 1533$ & $18.75 \pm 2.81$ \\
$\mathrm{Si}$ & 251.611 & $48.55 \pm 7.28$ & $177 \pm 27$ & $17.60 \pm 2.64$ \\
$\mathrm{Zn}$ & 213.856 & $124 \pm 19$ & $118 \pm 18$ & $0.50 \pm 0.08$ \\
\hline
\end{tabular}


In the present study, from the algal compost, extract was also obtained (mineral composition is presented in Table 2). For the comparison, the examples of the multielemental composition of the extracts obtained from green seaweeds by different extraction techniques are presented in Table 3.

Minerals and trace elements present in seaweed extracts enhance plant nutrition and have a critical role in plant development [32]. In the present study, the extract obtained from the algal compost was a very good source of $\mathrm{Mg}, \mathrm{Mn}$, $\mathrm{Na}, \mathrm{P}$, good of $\mathrm{Ca}$ and $\mathrm{K}$ and poor of $\mathrm{Cu}, \mathrm{Fe}, \mathrm{S}$ and $\mathrm{Zn}$ when compared with extracts obtained by other extraction techniques (e.g., supercritical fluid extraction (SFE), microwave assisted extraction (MAE), chemical extraction etc.). The multielemental composition of the tested seaweed extract was poorer than the compost, however, as it was indicated in the literature, are bioactive at low concentrations (diluted as 1:1000 or more) [19].

\section{The Phytotoxicity of the Products-Germination Tests}

In many studies, phytotoxicity analysis is carried out first in order to evaluate the utilitarian properties of the obtained compost. In the literature, it is suggested that composting of seaweeds reduced their phytotoxicity [3, 33]. Cuomo et al. [3] examined the phycotoxicity of compost produced from Ulva sp. on Lepidium sativum. It was indicated that a complete lack of phytotoxicity and the absence of any inhibitory effects on the germination rate of $L$. sativum seeds showed that the tested compost reached maturation state and had a good final quality [3]. In the present study, the obtained results showed that there were no phytotoxic effects of algal compost and compost extract in the cultivation of garden cress (Lepidium sativum) and radish (Raphanus sativus). The results of the germination tests after 7 days are presented in Fig. 1: (a) for garden cress and (b) for radish.

\section{Effect of Seaweed Compost and Compost Extract from the Compost on Garden Cress and Radish Yield}

In the present work, the preliminary germination tests were also used the evaluate the effect of algal compost as a natural organic fertilizer and compost extract as biostimulant of plant on the yield of the garden cress and radish. Dry weight of the cultivated plants in the examined groups is presented in Table 4. For both plants, the differences between the groups (control, algal compost, compost extract) were not statistically significant $(p<0.05)$. The tested products slightly increased the mass of the plants, however in both cases better results were obtained for compost extract, rather than for compost. In the case of garden cress, the mass of plants in the group with algal compost was $1.0 \%$ lower than in the control group, whereas in the group with compost extract higher by $4.1 \%$. For the radish, the mass of plants in both experimental groups was higher than in the control group-by $6.2 \%$ for algal compost and by $8.8 \%$ for compost extract.

Literature indicates that the application of algal compost improves the germination of seeds [28], plant growth and water stress resistance [34], water holding capacity $[13,34]$, plant height and weight $[11,14,35,36]$, resistance

Table 3 The examples of the multielemental composition of extracts obtained from green seaweeds

\begin{tabular}{lccccc}
\hline Element & $\begin{array}{l}\text { Polysiphonia, } \\
\text { Ulva, Cladophora } \\
\text { SFE [20] (mg/L) }\end{array}$ & $\begin{array}{l}\text { Baltic green seaweeds } \\
\text { Extract obtained by } \\
\text { alkaline extraction with } \\
\text { KOH [44] }(\mathrm{mg} / \mathrm{L})\end{array}$ & $\begin{array}{l}\text { Polysiphonia, Ulva, } \\
\text { Cladophora } \\
\text { Extract obtained by } \\
\text { MAE } 60{ }^{\circ} \mathrm{C}[45] \\
(\mathrm{mg} / \mathrm{L})\end{array}$ & $\begin{array}{l}\text { Baltic green seaweeds } \\
\text { Extract obtained by acidic } \\
\text { [46] }(\mathrm{mg} / \mathrm{L})\end{array}$ & $\begin{array}{l}\text { Extract obtained by } \\
\text { heating for } 45 \mathrm{~min} \text { in } \\
60{ }^{\circ} \mathrm{C}[18](\mathrm{mg} / \mathrm{L})\end{array}$ \\
\hline $\mathrm{Ca}$ & $1060 \pm 210$ & $127 \pm 19$ & $365 \pm 54$ & $230 \pm 34$ & 158 \\
$\mathrm{Cu}$ & $6.27 \pm 0.94$ & $0.79 \pm 0.12$ & $0.11 \pm 0.02$ & $0.04 \pm 0.01$ & 1.15 \\
$\mathrm{Fe}$ & $9.24 \pm 1.39$ & $30.17 \pm 4.52$ & $2.87 \pm 0.43$ & $3.76 \pm 0.56$ & 5.2 \\
$\mathrm{~K}$ & $51.76 \pm 7.76$ & $28,260 \pm 5650^{\mathrm{a}}$ & $950 \pm 140$ & $143 \pm 21$ & 175 \\
$\mathrm{Mg}$ & $406 \pm 61$ & $34.11 \pm 5.12$ & $322 \pm 48$ & $28.50 \pm 4.40$ & 108 \\
$\mathrm{Mn}$ & $6.56 \pm 0.98$ & $1.96 \pm 0.29$ & $3.07 \pm 0.46$ & $1.20 \pm 0.18$ & $\mathrm{n} . \mathrm{a}$. \\
$\mathrm{Na}$ & $965 \pm 145$ & $620 \pm 90$ & $1250 \pm 250$ & $46.20 \pm 6.90$ & 295 \\
$\mathrm{P}$ & $43.19 \pm 6.48$ & $6050 \pm 1210^{\mathrm{b}}$ & $32.90 \pm 4.90$ & $10.10 \pm 1.50$ & 45 \\
$\mathrm{~S}$ & $9300 \pm 1900$ & $1350 \pm 270$ & $700 \pm 105$ & $532 \pm 80$ & 55 \\
$\mathrm{Zn}$ & $5.25 \pm 0.79$ & $6.86 \pm 1.03$ & $0.17 \pm 0.03$ & $0.65 \pm 0.10$ & 1.3 \\
\hline
\end{tabular}

${ }^{\mathrm{a}} \mathrm{KOH}$ was used as a solvent; ${ }^{\mathrm{b}} \mathrm{H}_{3} \mathrm{PO}_{4}$ was used to neutralize the extract to $\mathrm{pH} 7$ 

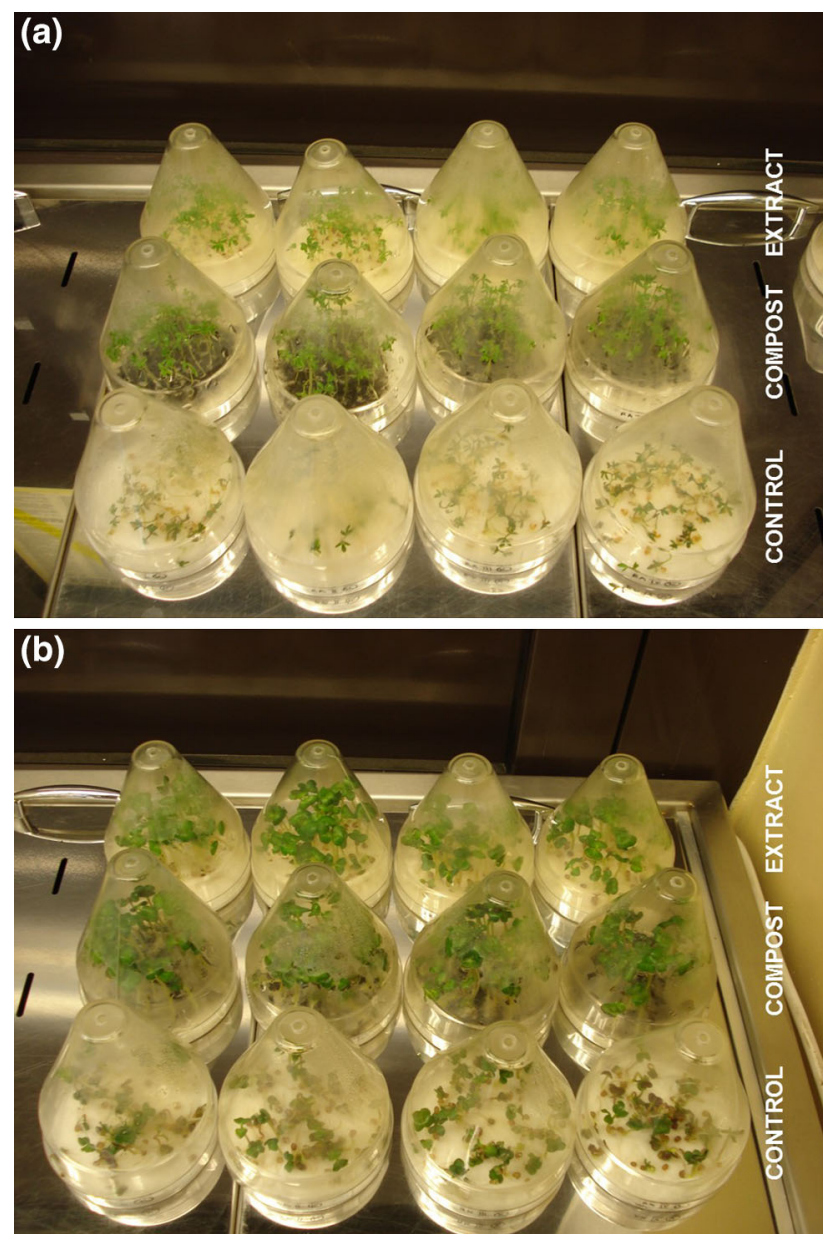

Fig. 1 Germination tests on a garden cress (Lepidium sativum) and b radish (Raphanus sativus) after 7 days

to diseases on plants (e.g., tomato) [11], as well as the content of micro- and macroelements in the cultivated plants $[14,36]$. Some of the examples of the action of seaweed extracts in the plant cultivation are presented below.

In the work of Haq et al. [28], germination tests were performed on maize (Zea mays). It was shown that in the group with compost (algae and cow dung, 2:1), the germination was $78 \%$, whereas in the group with cow dung$60 \%$. Eyras et al. [34] evaluated the effect of compost produced from seaweed and sawdust (4:1) on the growth of tomato plants (Licopersicum esculentum var. platense). It was found that the increase of tomato was proportional to the compost doses ( 0 - control, 10, 25, 50 and $100 \%$ compost in a substratum of sand). Results showed that the addition of the compost increased plant growth and water holding capacity. In the group with $100 \%$ compost, all plants flowered and $83 \%$ of them bore fruit and survived the imposed water stress, whereas plants in the group with NPK fertilizer were severely affected by water stress and only one plant per treatment survived. Vendrame and Moore [13] also confirmed that substrates, designated for plant cultivation, containing seaweed compost (1:1; seaweed compost and yard trimmings compost) had greater water holding capacities than substrates containing the mixture of biosolids compost and yard trimmings compost $(1: 1)$. It was suggested that seaweed compost could be potentially substituted for peat in the growing substrate. Illera-Vives et al. [35] noted that the highest dose of the compost (66 t/ha), produced from drift seaweed, mackerel waste and pine bark, increased the tomato yields (also fruit weight and fruit diameter) when compared with other groups: organic fertilizers-broiler litter (higher by $12.2 \%$ ), slow-release NPK treatment (higher by $17.6 \%$ ) and a control treatment without fertilizers (higher by $18.3 \%$ ). These beneficial effects of the compost could result not only from the supplementation of nutrients but also from the improvement of the soil physical conditions due to high alginate content in algae, as well as the content of growth regulators, such as auxins and cytokinins. Eyras et al. [11] found that the compost produced from algae and lingocellulosic material (3:1) aged 9 and 20 months influenced significantly the total weight of tomatoes, which was higher by 35 and $65 \%$, respectively when compared to the control group (soil without amendment). The doses (5 and $10 \mathrm{~kg} / \mathrm{m}^{2}$ ) did not show any significant differences within compost.

\section{Effect of Seaweed Compost and Compost Extract on the Multielemental Composition of Garden Cress and Radish}

Seaweed compost, applied just before cultivation, provides a "stimulus" effect that makes nutrients rapidly available to the plants on a relatively long period of time. It was found that the compost is suitable for intensive cultivation
Table 4 Dry mass of the cultivated plants in the examined groups

\begin{tabular}{lll}
\hline Group & & Dry mass $[\mathrm{g}(\mathrm{mean} \pm \mathrm{SD}) ; \mathrm{N}=4]$ \\
\hline Garden cress (Lepidium sativum) & Control—distilled water & $0.061 \pm 0.001$ \\
& Algal compost & $0.060 \pm 0.001$ \\
& Compost extract & $0.063 \pm 0.003$ \\
Radish (Raphanus sativus) & Control—distilled water & $0.306 \pm 0.026$ \\
& Algal compost & $0.325 \pm 0.008$ \\
& Compost extract & $0.333 \pm 0.023$ \\
\hline
\end{tabular}


both in the field and the greenhouse [5]. Among the main categories of plant biostimulants-seaweed extracts and botanicals, humic and fulvic acids, protein hydrolysates and other $\mathrm{N}$-containing compounds, plant growth promoting Rhizobacteria, the function of the improvement of mineral composition of plant tissues (biofortification) is assigned to seaweed extracts [37].

In the literature, the effect of algal products (compost, extracts) on the mineral composition of the cultivated plants is rarely studied. Usually it is limited to the main macronutrient $-\mathrm{N}, \mathrm{P}$ and $\mathrm{K}$. Table 5 presents the multielemental composition of the cultivated plants, garden cress and radish, treated with algal compost and compost extract.

For both plants, the addition of algal compost increased the content of microelements such as: B: by $108 \%$ for garden cress and by $200 \%$ for radish, $\mathrm{Cu}$ : by $6.8 \%$ and $54 \%$, Mn: by $25 \%$ and $73 \%$, Si: by $202 \%$ and $567 \%$, Zn: by $17 \%$ and $62 \%$ and macroelements such as: Ca: by $16 \%$ and $53 \%$, respectively, K: by $290 \%$ and by $189 \%$, $\mathrm{Mg}$ : by $26 \%$ and $26.5 \%$, respectively when compared with the control group.

The soil application of the compost extract increased the content of microelements such as: B: by $134 \%$ in garden cress and by $122 \%$ in radish, Mn: by $20 \%$ and $30 \%, \mathrm{Zn}$ : by $32 \%$ and $54 \%$ and macroelement K: by $276 \%$ and $153 \%$, respectively, when compared with the control group.

In the literature it is suggested that algal extracts can stimulate the expression of genes that encode transporters of micronutrients (e.g. $\mathrm{Cu}, \mathrm{Fe}, \mathrm{Zn}$ ) [38]. Billard et al. evaluated the effect of extract from brown seaweedAscophyllum nodosum on the multielemental composition (N, S, K, Ca, P, Mg, Fe, Na, Mn, B, Si, Cu, and $\mathrm{Zn}$ ) of oilseed rape (Brassica napus). The application of Ascophyllum extract stimulated root growth and macronutrient uptake of $\mathrm{N}, \mathrm{S}, \mathrm{K}$, and $\mathrm{P}$. Moreover, the extract also increased the content of $\mathrm{Mg}, \mathrm{Mn}, \mathrm{Na}$, and $\mathrm{Cu}$ in plants and root-to-shoot translocation of $\mathrm{Fe}$ and $\mathrm{Zn}$. These observations were associated with an increased expression of a $\mathrm{Cu}$ transporter (COPT2) and NRAMP3, a gene involved in $\mathrm{Fe}$ and $\mathrm{Zn}$ translocation [38].

In the present work we checked, which algae-based product had beneficial effect on the multielemental composition of tested plants. The content of micro- and macroelements in garden cress was mainly influenced by the application of compost, especially the content of $\mathrm{Cu}$ was by $16 \%$ higher than for the group with compost extract, $8.0 \%$ higher for $\mathrm{Ca}, 6.0 \%$ higher for $\mathrm{S}$ and $4.0 \%$ higher for $\mathrm{K}$ and $\mathrm{Mn}$. Better results in terms of

Table 5 Multielemental composition of the cultivated plants

\begin{tabular}{|c|c|c|c|c|c|c|}
\hline \multirow[t]{2}{*}{ Element } & \multicolumn{3}{|c|}{ Garden cress (Lepidium sativum) } & \multicolumn{3}{|c|}{ Radish (Raphanus sativus) } \\
\hline & $\begin{array}{l}\text { Control } \\
{[\mathrm{mean} \pm \mathrm{SD}} \\
(\mathrm{mg} / \mathrm{kg} \mathrm{d} . \mathrm{m} .) \\
\mathrm{N}=4]\end{array}$ & $\begin{array}{l}\text { Algal compost } \\
{[\text { mean } \pm \mathrm{SD}(\mathrm{mg} / \mathrm{kg}} \\
\text { d. } \mathrm{m} .) ; \mathrm{N}=4]\end{array}$ & $\begin{array}{l}\text { Compost extract } \\
{[\text { mean } \pm \mathrm{SD}(\mathrm{mg} / \mathrm{kg}} \\
\text { d. } \mathrm{m} .) ; \mathrm{N}=4]\end{array}$ & $\begin{array}{l}\text { Control } \\
{[\text { mean } \pm \mathrm{SD}} \\
(\mathrm{mg} / \mathrm{kg} \mathrm{d} . \mathrm{m} .) \\
\mathrm{N}=4]\end{array}$ & $\begin{array}{l}\text { Algal compost } \\
{[\text { mean } \pm \mathrm{SD}(\mathrm{mg} / \mathrm{kg}} \\
\text { d. } \mathrm{m} .) ; \mathrm{N}=4]\end{array}$ & $\begin{array}{l}\text { Compost extract } \\
{[\text { mean } \pm \mathrm{SD}(\mathrm{mg} / \mathrm{kg}} \\
\text { d. } \mathrm{m} .) ; \mathrm{N}=4]\end{array}$ \\
\hline $\mathrm{Al}$ & $3.16 \pm 0.47$ & $78.95 \pm 11.84$ & $17.69 \pm 2.65$ & $5.13 \pm 0.77$ & $36.96 \pm 5.54$ & $4.29 \pm 0.64$ \\
\hline B & $12.82 \pm 1.92$ & $26.63 \pm 3.99$ & $29.98 \pm 4.50$ & $6.75 \pm 1.01$ & $20.23 \pm 3.03$ & $15.02 \pm 2.25$ \\
\hline $\mathrm{Ca}$ & $4346 \pm 869$ & $5028 \pm 1006$ & $4626 \pm 925$ & $7497 \pm 1499$ & $11,478 \pm 2296$ & $7448 \pm 1490$ \\
\hline $\mathrm{Cd}$ & $0.19 \pm 0.03$ & $0.22 \pm 0.03$ & $0.20 \pm 0.03$ & $0.24 \pm 0.04$ & $0.35 \pm 0.05$ & $0.25 \pm 0.04$ \\
\hline $\mathrm{Cr}$ & $2.29 \pm 0.34$ & $1.06 \pm 0.16$ & $0.99 \pm 0.15$ & $0.35 \pm 0.05$ & $0.66 \pm 0.10$ & $0.41 \pm 0.06$ \\
\hline $\mathrm{Cu}$ & $5.03 \pm 0.75$ & $5.37 \pm 0.81$ & $4.53 \pm 0.68$ & $4.22 \pm 0.63$ & $6.49 \pm 0.97$ & $5.43 \pm 0.81$ \\
\hline $\mathrm{Fe}$ & $173 \pm 26$ & $167 \pm 25$ & $123 \pm 18$ & $88.60 \pm 13.29$ & $165 \pm 25$ & $84.69 \pm 12.70$ \\
\hline $\mathrm{K}$ & $13,246 \pm 2649$ & $51,719 \pm 10344$ & $49,779 \pm 9956$ & $9800 \pm 1960$ & $28,285 \pm 5657$ & $24,753 \pm 4951$ \\
\hline $\mathrm{Mg}$ & $5883 \pm 1177$ & $7415 \pm 1483$ & $7560 \pm 1512$ & $6341 \pm 1268$ & $8024 \pm 1605$ & $5285 \pm 1057$ \\
\hline Mn & $43.32 \pm 6.50$ & $54.18 \pm 8.13$ & $52.12 \pm 7.82$ & $32.25 \pm 4.84$ & $55.59 \pm 8.34$ & $41.78 \pm 6.27$ \\
\hline Mo & $2.56 \pm 0.38$ & $2.41 \pm 0.36$ & $2.05 \pm 0.31$ & $0.77 \pm 0.12$ & $0.77 \pm 0.12$ & $0.73 \pm 0.11$ \\
\hline $\mathrm{Na}$ & $8661 \pm 1732$ & $6917 \pm 1383$ & $7527 \pm 1505$ & $2867 \pm 573$ & $11,415 \pm 2283$ & $6895 \pm 1379$ \\
\hline $\mathrm{P}$ & $16,827 \pm 3365$ & $16,126 \pm 3225$ & $14,975 \pm 2995$ & $19,626 \pm 3925$ & $21,243 \pm 4249$ & $12,691 \pm 2538$ \\
\hline $\mathrm{Pb}$ & $1.14 \pm 0.17$ & $0.16 \pm 0.02$ & $<$ LLD & $0.01 \pm 0.00$ & $0.13 \pm 0.02$ & $<$ LLD \\
\hline $\mathrm{S}$ & $11,660 \pm 2332$ & $19,220 \pm 3844$ & $18,014 \pm 3603$ & $33,817 \pm 6763$ & $33,515 \pm 6703$ & $21,749 \pm 4350$ \\
\hline $\mathrm{Si}$ & $51.59 \pm 7.74$ & $156 \pm 23$ & $52.55 \pm 7.88$ & $15.90 \pm 2.39$ & $106 \pm 16$ & $15.12 \pm 2.27$ \\
\hline $\mathrm{Zn}$ & $145 \pm 22$ & $169 \pm 25$ & $191 \pm 29$ & $75.24 \pm 11.29$ & $122 \pm 18$ & $116 \pm 17$ \\
\hline
\end{tabular}

$<$ LLD—Below detection limit 
multielemental composition were obtained for the second tested plant-radish. The content of Na was $66 \%$ higher in the group with compost, than with the extract, $\mathrm{Ca}$ by $35 \%$, Mg by $34 \%$, B by $26 \%$, Mn by $25 \%, \mathrm{Cu}$ by $16 \%$, K by $12 \%$ and $\mathrm{Zn}$ by $5.0 \%$. Boron was a trace element that appeared to be provided by seaweed biomass in both treatments. Similar observation was noted by Winberg et al. [15], who evaluated the Microdictyon umbilicatum bloom biomass as an agricultural compost conditioner for native and commercial plants.

In our previous work, compost and extract obtained from the composting mixture (seaweed-Fucus sp., ecological hay, grass, sawdust and spent mushroom substrate) were examined on garden cress. It was found that the extract better affected the content of macroelements in plants than compost, however these differences were slight (2.0\% more of $\mathrm{Ca}, 1.0 \%$ more of $\mathrm{K}, 11 \%$ more of $\mathrm{Mg}$ and $15 \%$ more of $\mathrm{S})$. On the other side, examined compost better influenced the content of microelements (B-35\% more, $\mathrm{Cu}-15 \%$ more, $\mathrm{Mn}-28 \%$ more, $\mathrm{Zn}-5.0 \%$ more and $\mathrm{Fe} \sim 2$ times more) than the extract [30]. Mininni et al. [36] tested the feasibility of the use of compost produced from the residues of alga Posidonia oceanica, vegetables (broccoli, fennel and celery scraps) and grapevine pruning as partial substitutes for peat in the growing media used in the cultivation of melon and tomato. For both plant, the best results in terms of the content of micro- and macroelements were obtained for growing media consisted of the composted mixture $(1: 2: 2)-25 \%$ and peat $-75 \%$. For melon the increase was observed for $\mathrm{Ca}, \mathrm{Cu}, \mathrm{Mn}$ and $\mathrm{Zn}$, for tomato for $\mathrm{K}, \mathrm{Ca}, \mathrm{Mg}, \mathrm{Na}, \mathrm{Fe}, \mathrm{Mn}$ and $\mathrm{Zn}$ when compared with the control group_-peat. Morand et al. [5] indicated that as growth media, algal composts should be mixed with dirt, sand, turf or artificial supports to reduce their strength for agricultural use.

Crouch et al. [39] found that the application of seaweed concentrate (Kelpak) significantly increased the yield and the amounts of $\mathrm{Ca}, \mathrm{K}$ and $\mathrm{Mg}$ in the leaves of lettuce receiving an adequate supply of nutrients. These results were also confirmed by Sosnowski et al. [40], who examined the effect of the extract from Ecklonia maxima (Kelpak) on selected micro- and macroelements in aerial biomass of hybrid alfalfa. The application of this seaweed extract led to an increase of the content of P, K, Zn and Mn in alfalfa aerial biomass. The content of $\mathrm{Mg}, \mathrm{Ca}, \mathrm{Cu}$ and Mo did not change significantly in response to the tested extract. In the work of Abd El-Motty et al. [41] it was confirmed that the application of algal extract in different doses $(0.5,1.0$ and $2.0 \%)$ enhanced $\mathrm{N}, \mathrm{P}, \mathrm{K}$ and B content in the leaves of Keitte mango trees. Also in the case of the application of seaweed extract, obtained by the homogenization of red alga Kappaphycus alvarezii, an significant increase of the $\mathrm{N}, \mathrm{P}$ and $\mathrm{K}$ uptake by grains at higher concentrations (12.5 and $15 \%$ ) was observed when compared with control (water) [42]. Mancuso et al. [43] suggested that the presence of marine bioactive substances in seaweed extracts improved stomata uptake efficiency in treated plants compared to non-treated plants. From the presented examples it can be seen that algal extracts influenced mainly the content of macroelements in the cultivated plants. The main ingredients in extracts that affect plants are phytohormones (cytokinins, auxins), which are found in the composition of most seaweed concentrates [19, 40].

\section{Conclusions}

In the present work, a method of bioconversion of Baltic seaweeds, being the result of eutrophication in the coastal areas, was proposed. From algal biomass, compost and compost extract were produced. It was proposed to apply those preparations as natural organic fertilizer and plant growth biostimulant, respectively. The obtained products were characterized in terms of the content of micro- and macroelements and toxic metals using ICP-OES technique. Based on the obtained results it may be concluded that the resulting compost and extract were of good quality in terms of nutrient content and low toxic metal content. The content of $\mathrm{C}$ and $\mathrm{N}$ in the obtained compost decreased by 29 and $30 \%$, respectively when compared with the natural biomass of algae. The increase of micro- and macronutrients ( $\mathrm{Ca}$ by $36 \%, \mathrm{Cu}$ by $11 \%, \mathrm{Fe}$ and $\mathrm{P}$ by $9.5 \%$ ) in the compost was observed when compared with the raw biomass. The algal extract obtained from the compost was a source of $\mathrm{Mg}, \mathrm{Mn}, \mathrm{Na}, \mathrm{P}, \mathrm{Ca}$ and $\mathrm{K}$.

The phytotoxicity of algae-based products was evaluated in the germination tests on the garden cress (Lepidium sativum) and radish (Raphanus sativus). No phytotoxic effect was recorded. Additionally it was found that the examined products slightly increased the mass of the plants. For both plants, the addition of algal compost increased the content of microelements such as: $\mathrm{B}, \mathrm{Cu}, \mathrm{Mn}$, $\mathrm{Si}, \mathrm{Zn}$ and macroelements such as: $\mathrm{Ca}, \mathrm{K}$ and $\mathrm{Mg}$ when compared with the control group. The soil application of the algal extract increased the content of microelements such as: B, Mn, $\mathrm{Zn}$ and macroelement $\mathrm{K}$ when compared with the control group. Better elemental composition had plants treated with algal compost, rather than with extract. The obtained results show that composting technology can be used as a method to turn seaweed biomass into compost that can be used as organic amendments or fertilizers for agricultural systems. 


\section{Compliance with Ethical Standards}

Conflict of interest The authors declare that they have no conflict of interest.

Open Access This article is distributed under the terms of the Creative Commons Attribution 4.0 International License (http://crea tivecommons.org/licenses/by/4.0/), which permits unrestricted use, distribution, and reproduction in any medium, provided you give appropriate credit to the original author(s) and the source, provide a link to the Creative Commons license, and indicate if changes were made.

\section{References}

1. Maze, J., Morand, P., Potoky, P.: Stabilisation of 'Green tides' Ulva by a method of composting with a view to pollution limitation. J. Appl. Phycol. 5, 183-190 (1993)

2. Han, W., Clarke, W., Pratt, S.: Composting of waste algae: a review. Waste Manage. 34, 1148-1155 (2014)

3. Cuomo, V., Perretti, A., Palomba, I., Verde, A., Cuomo, A.: Utilisation of Ulva rigida biomass in the Venice Lagoon (Italy): biotransformation in compost. J. Appl. Phycol. 7, 479-485 (1995)

4. HELCOM.: Development of tools for assessment of eutrophication in the Baltic Sea Balt. Sea Environ. Proc. No. 104 (2006). http://www.helcom.fi/Lists/Publications/BSEP104.pdf. Accessed on 19 April 2016

5. Morand, P., Charlier, R.H., Maze, J.: European bioconversion projects and realizations for macroalgal biomass: Saint-Cast-LeGuildo (France) experiment. Hydrobiologia 204(205), 301-308 (1990)

6. McHugh, D.J.: Other uses of seaweeds. In: A guide to the seaweed industry, vol. 441. Chapter 9, pp. 91-99. FAO. Fisheries technical paper, Rome (2003). http://www.fao.org/3/a-y4765e. pdf. Accessed on 20 April 2016

7. Vallini, G., Pera, A., Cecchi, F., Valdrighi, M.M., Sicurani, M.A.: Compost stabilization of algal biomass drawn in eutrophic lagoon ecosystems. Compost Sci. Util. 1, 49-53 (1993)

8. Cole, A.J., Roberts, D.A., Garside, A.L., de Nys, R., Paul, N.A.: Seaweed compost for agricultural crop production. J. Appl. Phycol. 28, 629-642 (2016)

9. Michalak, I., Chojnacka, K.: Algal compost-toward sustainable fertilization. Rev. Inorg. Chem. 33, 161-172 (2013)

10. López-Mosquera, M.E., Fernández-Lema, E., Villares, R., Corral, R., Alonso, B., Blanco, C.: Composting fish waste and seaweed to produce a fertilizer for use in organic agriculture. Proc. Environ. Sci. 9, 113-117 (2011)

11. Eyras, M.C., Defossé, G.E., Dellatorre, F.: Seaweed compost as an amendment for horticultural soils in Patagonia, Argentina. Compost Sci. Util. 16, 119-124 (2008)

12. Eghball, B.: Soil properties as influenced by phosphorus-and nitrogen-basedmanure and compost applications. Agron. J. 94, $128-135$ (2002)

13. Vendrame, W., Moore, K.K.: Comparison of herbaceous perennial plant growth in seaweed compost and biosolids compost. Compost Sci. Util. 13, 122-126 (2005)

14. Lacatusu, R., Capatana, R., Lacatusu, A.R., Meghea, A.: A new compost for organic farming. Testing by plants. SGEM2015 Conference Proceedings. 15th International Multidisciplinary Scientific GeoConference SGEM 2015, www.sgem.org, June 18-24, 2015, Book 3, Vol. 2, pp. 11-18 (2015)

15. Winberg, P.C., DeMestre, C., Willis, S.: Evaluating Microdictyon umbilicatum bloom biomass as an agricultural compost conditioner for native and commercial plants. Report to Shoalhaven City Council, 30p. (2011). http://ro.uow.edu.au/smfc/1. Accessed on 22 April 2016

16. Illera-Vives, M., Seoane Labandeira, S., López-Mosquera, M.E.: Production of compost from marine waste: evaluation of the product for use in ecological agriculture. J. Appl. Phycol. 25, 1395-1403 (2013)

17. Abou El-Yazied, A., El-Gizawy, A.M., Ragab, M.I., Hamed, E.S.: Effect of seaweed extract and compost treatments on growth, yield and quality of snap bean. J. Am. Sci. 8, 1-20 (2012). http://www.sciencepub.net/american

18. Selvam, G.G., Sivakumar, K.: Effect of foliar spray from seaweed liquid fertilizer of Ulva reticulata (Forsk.) on Vigna mungo L. and their elemental composition using SEM-energy dispersive spectroscopic analysis. Asian Pac. J. Reprod. 2, 119-125 (2013)

19. Khan, W., Rayirath, U.P., Subramanian, S., Jithesh, M.N., Rayorath, P., Hodges, D.M., Critchley, A.T., Craigie, J.S., Norrie, J., Prithiviraj, B.: Seaweed extracts as biostimulants of plant growth and development. J. Plant Growth Regul. 28, 386-399 (2009)

20. Michalak, I., Górka, B., Wieczorek, P.P., Rój, E., Lipok, J., Łęska, B., Messyasz, B., Wilk, R., Schroeder, G., DobrzyńskaInger, A., Chojnacka, K.: Supercritical fluid extraction of algae enhances levels of biologically active compounds promoting plant growth. Eur. J. Phycol. 51, 243-252 (2016)

21. Alvarado, D., Buitrago, E., Sole, M., Frontado, K.: Experimental evaluation of a composted seaweed extract as microalgal culture media. Aquacult. Int. 16, 85-90 (2008)

22. Gopinathan, M., Thirumurthy, M.: Evaluation of phytotoxicity for compost from organic fraction of municipal solid waste and paper \& pulp mill sludge. Environ. Res. Eng. Manage. 1(59), 47-51 (2012)

23. Greger, M., Malm, T., Kautsky, L.: Heavy metal transfer from composted macroalgae to crops. Eur. J. Agron. 26, 257-265 (2007)

24. Graves, R.E., Hattemer, G.M.: Chapter 2-Composting, Part 637-Environmental Engineering, In: National Engineering Handbook (2010). http://directives.sc.egov.usda.gov/Open NonWebContent.aspx?content=28910.wba. Accessed on 26 April 2016

25. Wosnitza, T.M.A., Barrantes, J.G.: Utilization of seaweed Ulva sp. in Paracas Bay (Peru): experimenting with compost. J. Appl. Phycol. 18, 27-31 (2005)

26. Irshad, M., Eneji, A.E., Hussain, Z., Ashraf, M.: Chemical characterization of fresh and composted livestock manures. J. Soil Sci. Plant Nutr. 13, 115-121 (2013)

27. Grabowski, J.: The chemical composition of natural fertilizers. Białystok. OSCh-R. P. 1. (2009)

28. Haq, T., Khan, F.A., Begum, R., Munshi, A.B.: Bioconversion of drifted seaweed biomass into organic compost collected from the Karachi coast. Pak. J. Bot. 43, 3049-3051 (2011)

29. Orquin, R., Abad, M., Noguera, P., Puchades, R., Maquieira, A.: Composting of Mediterranean seagrass and seaweed residues with yard waste for horticultural purposes. Acta Hortic. 549, 29-35 (2001)

30. Michalak, I., Tuhy, Ł., Chojnacka, K.: Co-composting of algae and effect of the compost on germination and growth of Lepidium sativum. Pol. J. Environ. Stud. 25, 1-9 (2016)

31. Directive of Polish Minister of Agriculture and Rural Development: Act on fertilizers and fertilization. J. Laws. No.119, Item 765 (2008)

32. Arioli, T., Mattner, S.W., Winberg, P.C.: Applications of seaweed extracts in Australian agriculture: past, present and future. J. Appl. Phycol. 27, 2007-2015 (2015)

33. Tang, J., Wang, M., Zhou, Q., Nagata, S.: Improved composting of Undaria pinnatifida seaweed by inoculation with Halomonas 
and Gracilibacillus sp. isolated from marine environments. Bioresour. Technol. 102, 2925-2930 (2011)

34. Eyras, M.C., Rostagno, C.M., Defossé, G.E.: Biological evaluation of seaweed composting. Compost Sci. Util. 6, 74-81 (1998)

35. Illera-Vives, M., Seoane Labandeira, S., Brito, L.M., López-Fabal, A., López-Mosquera, M.E.: Evaluation of compost from seaweed and fish waste as a fertilizer for horticultural use. Sci. Hortic. 186, 101-107 (2015)

36. Mininni, C., Bustamante, M.A., Medina, E., Montesano, F., Paredes, C., Pérez-Espinosa, A., Moral, R., Santamaria, P.: Evaluation of Posidonia seaweed-based compost as a substrate for melon and tomato seedling production. J. Hortic. Sci. Biotechnol. 88, 345-351 (2013)

37. du Jardin, P.: Plant biostimulants: Definition, concept, main categories and regulation. Sci. Hortic. 196, 3-14 (2015)

38. Billard, V., Etienne, P., Jannin, L., Garnica, M., Cruz, F., GarciaMina, J.M., Yvin, J.C., Ourry, A.: Two biostimulants derived from algae or humic acid induce similar responses in the mineral content and gene expression of winter oilseed rape (Brassica napus L.). J. Plant Growth Regul. 33(2), 305-316 (2014)

39. Crouch, I.J., Beckett, R.P., Van Staden, J.: Effect of seaweed concentrates on the growth and mineral nutrition of nutrient stress lettuce. J. Appl. Phycol. 2, 269-272 (1990)

40. Sosnowski, J., Jankowski, K., Wiśniewska-Kadżajan, B., Jankowska, J., Kolczarek, R.: Effect of the extract from Ecklonia maxima on selected micro- and macroelements in aerial biomass of hybrid alfalfa. J. Elementol. (2014). doi:10.5601/jelem.2014. 19.1.608

41. Abd El-Motty, E.Z., Shahin, M.F.M., El-Shiekh, M.H., Abd-ElMigeed, M.M.M.: Effect of algae extract and yeast application on growth, nutritional status, yield and fruit quality of Keitte mango trees. Agric. Biol. J. North Am. 1, 421-429 (2010)

42. Rathore, S.S., Chaudhary, D.R., Boricha, G.N., Ghosh, A., Bhatt, B.P., Zodape, S.T., Patolia, J.S.: Effect of seaweed extract on the growth, yield and nutrient uptake of soybean (Glycine max) under rainfed conditions. South Afr. J. Bot. 75, 351-355 (2009)

43. Mancuso, S., Azzarello, E., Mugnai, S., Briand, X.: Marine bioactive ubstances (IPA extract) improve foliar ion uptake and water tolerance in potted Vitis vinifera plants. Adv. Hortic. Sci. 20, 156-161 (2006)

44. Michalak, I., Tuhy, Ł., Chojnacka, K.: Extraction of seaweed with potassium lye. Przem. Chem. 93, 771-774 (2014). in Polish

45. Michalak, I., Tuhy, Ł., Chojnacka, K.: Seaweed extract by microwave assisted extraction as plant growth biostimulant. Open Chem. 13, 1183-1195 (2015)

46. Michalak, I., Chojnacka, K.: Use of extract from Baltic seaweeds produced by chemical hydrolysis in plant cultivation. Przem. Chem. 92, 1046-1049 (2013). in Polish 